\title{
Sediment variations and littoral transport at La Victoria Beach, Cádiz, Spain
}

\section{Variaciones sedimentarias y transporte litoral en Playa de la Victoria, Cádiz, España}

\author{
GE Avila-Serrano1*, MA Santa Rosa del Ríoํㅜ, G Anfuso-Melfi², J Benavente-González², \\ R Guardado-France ${ }^{1}$, O González-Yajimovich ${ }^{1}$, EK Velázquez-González ${ }^{3}$
}

\begin{abstract}
${ }^{1}$ Departamento de Geología, Facultad de Ciencias Marinas, Universidad Autónoma de Baja California, Carretera TijuanaEnsenada Km 103, Apartado postal 453, Ensenada, CP 22870, Baja California, México.* E-mail: gavila@uabc.mx

${ }^{2}$ Departamento de Geología, Facultad de Ciencias del Mar y Ambientales, Universidad de Cádiz, Puerto Real, España. ${ }^{3}$ División de Ciencias Biológicas y de la Salud, Universidad Autónoma Metropolitana, México.
\end{abstract}

\begin{abstract}
The evolution of La Victoria Beach, located in the province of Cádiz (Spain), was evaluated from February to October 2004 by comparing the lithology and slope of two beach sections: the northern or Final Victoria (FV) section and the southern or Hotel Victoria (HV) section. Textural parameters and $\mathrm{CaCO}_{3}$ content of 24 sediment samples were obtained, and littoral transport was determined by fluorescent tracers. Topographic profiles were measured every 15 days using a total station during low spring tides. The sediment samples were analyzed by the method of moments and their textural parameters (mean, asymmetry, sorting, and kurtosis) calculated. The textural analysis showed that the sediment in section FV during the study period was moderately well classified and extremely leptokurtic, whereas section HV had two sediment groups: fine sands near the breaker zone and very fine pebbles at the berm; however, the winter period was evident in both sections. $\mathrm{The}^{\mathrm{CaCO}} \mathrm{C}_{3}$ content varied between $3 \%$ and $9 \%$, indicating beach instability. The direction of the littoral transport, in agreement with the region's behavior, was NW-SE, and showed a displacement of $130 \mathrm{~m}$ at $0.29 \mathrm{~m} \mathrm{~s}^{-1}$.
\end{abstract}

Key words: beach profiles, textural parameter, winter period.

\section{Resumen}

Se evaluó la evolución de Playa de la Victoria, localizada en la provincia de Cádiz (España), para el periodo de febrero a octubre de 2004, comparando dos secciones de playa, la sección norte o Final Victoria (FV) y la sección central u Hotel Victoria (HV), su litología y pendiente. Se determinaron los parámetros texturales y contenido de $\mathrm{CaCO}_{3}$ de 24 muestras de sedimento y se obtuvo el transporte litoral por medio de trazadores fluorescentes. Se midieron perfiles topográficos con una estación total durante la bajamar viva cada 15 días. Las muestras de sedimento fueron analizadas por el método de momentos y se calcularon sus parámetros texturales (media, asimetría, clasificación y curtosis). Los resultados muestran que, durante el periodo estudiado, el sedimento en la sección FV estuvo moderadamente bien clasificado y extremadamente leptocúrtico, mientras que la sección HV el análisis mostró dos grupos de sedimento: arenas finas cerca de la rompiente y guijarros muy finos en la berma; sin embargo, en ambas secciones fue evidente el periodo de invierno. El contenido de $\mathrm{CaCO}_{3}$ varió entre $3 \%$ y $9 \%$, lo que indica inestabilidad de la playa. La dirección del transporte litoral fue NW-SE, coincidiendo con el comportamiento de la región, y se encontró un desplazamiento de $130 \mathrm{~m}$ a una velocidad de $0.29 \mathrm{~m} \mathrm{~s}^{-1}$.

Palabras clave: parámetros texturales, perfiles de playa, periodo de invierno.

\section{Introduction}

Coastal areas have always attracted humans. Many of the large ancient cities were located in natural harbours; such is the case of Cádiz (Spain). The motives for settling such areas have differed and changed over the centuries, from primarily practical purposes (fishing, industry, transport) in the beginning to recreational or scenic reasons in more recent times (Benavente 2000). This has led to a large concentration of population along the coastline (Short 1979, CERC 1984, Komar 1998).

Beaches are gently sloping stretches of sand or gravel located along the shoreline, subject to wind, tide and wave

\section{Introducción}

Desde siempre la zona costera ha atraído la atención del ser humano, por lo que muchas de las grandes ciudades de la antigüedad se hallaban ubicadas en puertos naturales, como es el caso de Cádiz, en España. Las causas de dicha ocupación son muy diversass y se han ido multiplicando con el transcurrir de los siglos. En un principio ésta se ajustaba más a necesidades eminentemente prácticas (pesca, industria, transporte), a las que más recientemente se han sumado las de tipo lúdico y estético (Benavente 2000). Esto ha llevado a una alta concentración de población en las áreas más próximas a la costa (Short 1979, CERC 1984, Komar 1998). 
action, among other elements (Anfuso 2001). These energetic agents control the morphology of beaches, causing them to undergo constant changes (Carter 1988). Predicting possible future beach behaviour is therefore important in order to determine how it will affect the contiguous infrastructure.

To be able to understand changes in beach morphology, several studies have been conducted considering longshore and onshore drifts independently, which is feasible for sufficiently long and homogeneous coastal sections (Muñoz-Pérez 1996). Hence, beach profiles are an important indicator of shoreline variations since they allow us to reconstruct the morphology of the region, as well as infer the volume of sediment that is eroded or deposited in a certain time.

As a result of Spain's benign climate, both its Atlantic and Mediterranean coasts (especially in Andalusia) are popular destinations during several months of the year. The country has more than $8000 \mathrm{~km}$ of littoral, and the coastal zone (considered to be about $5 \mathrm{~km}$ wide) shelters $30 \%$ of the population, increasing to $82 \%$ in the summer (June-August). This means that $40 \%$ of the coastline has been urbanized or can be developed (MOPU 1991). Marinas and ports are the most evident examples of coastal infrastructures that play a key role in supporting the economy of nearby communities. The artificial regeneration or restoration of sandy beaches is also important to promote tourism and thus increase the input of foreign currency (Anfuso 2001). Between 1983 and 1993, 14\% of Spanish beaches were regenerated and almost a third of them were in Andalusia (CMAJA 1995). Coastline regression has been checked by regeneration projects, oftentimes accompanied by the construction of coastal structures, as occurs in the province of Cádiz. During the 1990s, these projects yielded annual investments of $€ 63,158.00$ (Muñoz et al. 2001).

Many beaches have a special morphology, such as those on rocky platforms that limit wave height and energy, which in turn reduces the volume of sediment deposited (Muñoz-Pérez 1996). Such beaches are found in the province of Cádiz (e.g., Regla Beach in Chipiona, Fuentebravía Beach in the port of Santa María, and La Victoria Beach in the city of Cádiz). The rocky-shore platform of these beaches is composed of sandstone and calcareous conglomerates of Pliocene age and its upper limit is around mean sea level (Muñoz-Pérez 1996).

Several regeneration projects have been implemented in recent years to increase beach width (berm and upper beach face) in several areas of Cádiz, especially those important for tourism. Among the most important beaches are La Victoria (Cádiz), La Barrosa (Chiclana), Camposoto (San Fernando), and Regla (Chipiona). These projects were undertaken after short-term point studies conducted by private companies under the supervision of the Ministry of the Environment's Demarcation of Andalusian Atlantic Coasts program (Anfuso 2001).

To contribute to the knowledge of beach planning and use, the purpose of this study was to determine the current geomorphology and coastal processes at La Victoria Beach.
Las playas son extensiones de arena o grava de poca pendiente que se encuentran ubicadas a un costado del mar. Estas extensiones de arena se ven sometidas a la acción del viento, mareas y oleaje, entre las más importantes (Anfuso 2001). Dichos agentes energéticos son los que controlan la morfología de las playas, ocasionando que éstas se mantengan en constante cambio (Carter 1988). Por las consecuencias que puedan tener sobre la infraestructura construida adyacente a la línea de costa, es de gran importancia poder predecir los posibles cambios que a futuro pueden presentar las playas.

Para poder entender los cambios morfológicos de las playas, se han hecho diferentes estudios en los cuales se consideran los fenómenos perpendiculares y paralelos a la playa de manera independiente, lo cual puede funcionar para tramos de costa lo suficientemente largos y homogéneos (Muñoz-Pérez 1996). Por ello los perfiles de playa son un indicador importante de las variaciones de la línea de costa, ya que nos permiten reconstruir la morfología de la región, así como inferir el volumen de sedimento que es erosionado o depositado en un determinado tiempo.

En España, las buenas condiciones climáticas hacen que el ambiente costero resulte atractivo durante varios meses del año, tanto en la costa mediterránea como en la vertiente atlántica, especialmente en Andalucía. Las costas españolas cuentan con $8000 \mathrm{~km}$ de litoral y, si se considera un ancho de $5 \mathrm{~km}$ de la zona costera, éstas zonas albegan actualmente al $30 \%$ de la población, incrementándose temporalmente al $82 \%$ en el verano (junio a agosto). Esta situación ha provocado que el $40 \%$ de la costa esté urbanizada o sea urbanizable (MOPU 1991). Los ejemplos más evidentes de infraestructuras en la línea de costa son las marinas y los puertos, que se utilizan para satisfacer necesidades económicas de las ciudades costeras. Asimismo, la regeneración o realimentación artificial de las playas permite contar con mayores extensiones de arena, lo cual es un gran atractivo turístico y propicia la entrada de divisas al país (Anfuso 2001). Entre 1983 y 1993, se regeneró el $14 \%$ de las playas españolas y casi la tercera parte de estas labores fueron realizadas en las costas de Andalucía (CMAJA 1995). El retroceso de la línea de costa en España se ha combatido con obras de regeneración, muchas veces acompañadas de la construcción de estructuras costeras, como sucede en la provincia de Cádiz. En la década de 1990 se realizaron inversiones de $€ 63,158.00$ anuales para frenar o revertir estos procesos (Muñoz et al. 2001).

Existen playas con una morfología especial, tales como las que están sobre lajas rocosas que limitan la altura de las olas así como su energía, produciendo una disminución en el volumen de sedimento depositado (Muñoz-Pérez 1996). En la provincia de Cádiz se pueden encontrar playas de este tipo, como son las playas de Regla en Chipiona, Fuentebravía en el Puerto de Santa María y de la Victoria en la ciudad de Cádiz. Estas playas presentan en su base una laja rocosa constituida por areniscas y conglomerados calcáreos del Plioceno, cuya cota superior oscila alrededor del nivel medio del mar (MuñozPérez 1996). 


\section{Material and methods}

La Victoria Beach $\left(36^{\circ} 52^{\prime} \mathrm{N}, 6^{\circ} 27^{\prime} \mathrm{W}\right)$ is located on the south Atlantic coast of Spain (fig. 1), in the southwestern part of the city of Cádiz. Two sections of the beach were considered for this study: (1) the northern section denominated Final Victoria (FV), which delimits the southern pier of Santa María del Mar Beach and has a rocky platform that serves as natural protection against incident waves; and (2) the central section denominated Hotel Victoria (HV), which is a wave-exposed dissipative beach located in front of a hotel of the same name.

Profiles were made perpendicular to the beach using a Leica TC407 total station and a prism with a graduated $(5 \mathrm{~m})$ base. This station allows measurement of vertical and horizontal angles, and has a filial cross with a pair of measuring lines that are used to calculate the difference in beach height (distance and slope). Differential leveling (King 1972), the classical method employed in morphodynamic studies, was used. The topographic profiles were spaced homogeneously, every

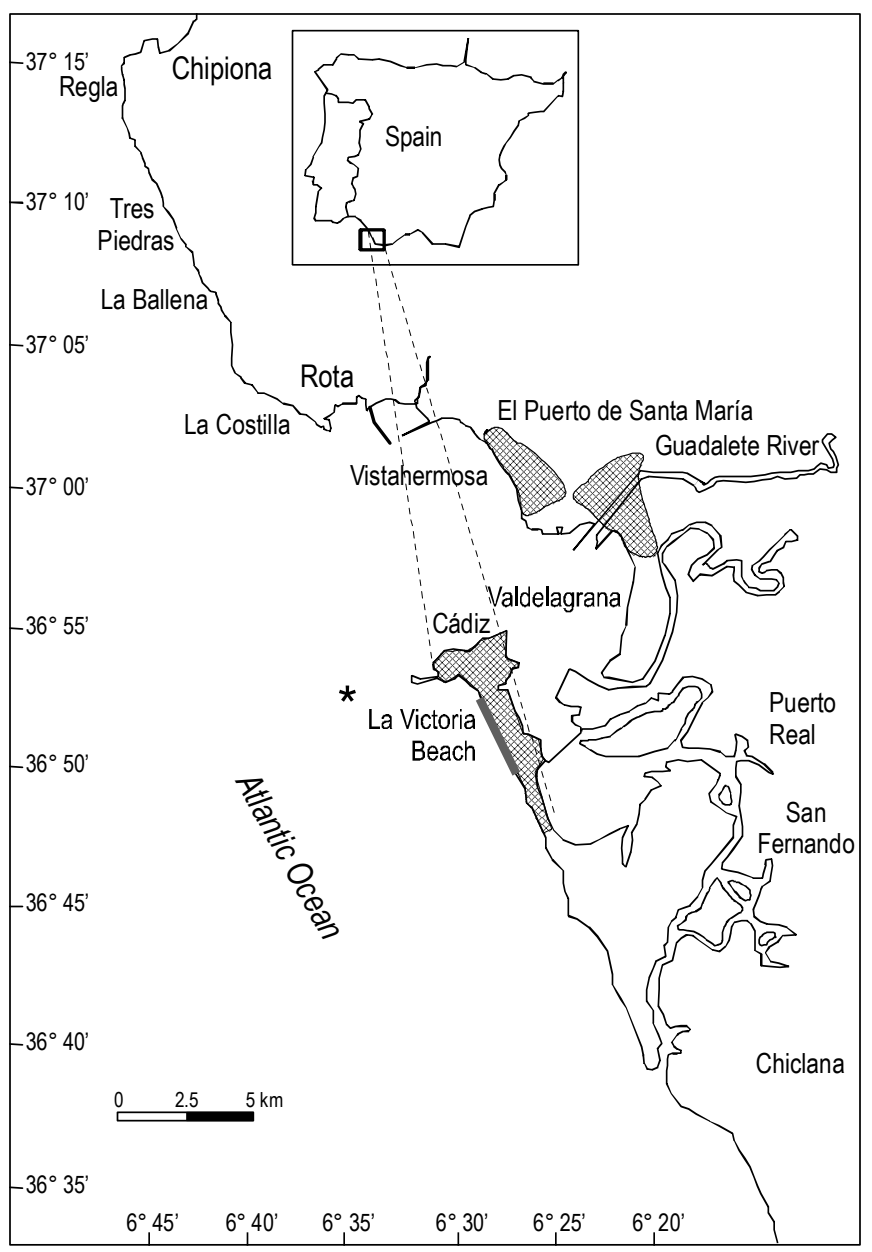

Figure 1. Map of the study area showing the location and extension of the coastline at La Victoria Beach in SW Spain.

Figura 1. Mapa de localización del área de que muestra la ubicación y extensión de la línea de costa en Playa de la Victoria al SO de Espana.
En los últimos años se han llevado a cabo varios proyectos de regeneración de playas con el fin de ampliar su ancho (berma y parte superior de la cara de la playa) en diferentes áreas de Cádiz, particularmente en áreas de importancia turística como las playas de la Victoria (Cádiz), La Barrosa (Chiclana), Camposoto (San Fernando) y Regla (Chipiona), entre las más importantes. Estas obras de regeneración han sido efectuadas tras estudios puntuales de corta duración realizados por empresas privadas bajo la supervisión de la Demarcación de Costas Andalucía-Atlántico (Anfuso 2001).

Como una contribución al conocimiento aplicable a la planeación y manejo de las playas, el presente trabajo se centró en determinar la geomorfología y los procesos costeros actuales en Playa de la Victoria.

\section{Materiales y métodos}

Playa de la Victoria $\left(36^{\circ} 52^{\prime} \mathrm{N}, 6^{\circ} 27^{\prime} \mathrm{W}\right)$ se localiza en la zona suratlántica española (fig. 1), en el municipio de Cádiz, donde se extiende desde la zona urbana ocupando la parte occidental de la ciudad. Para este estudio se consideraron dos secciones de la playa: (1) la sección norte o Final Victoria (FV), limita con el espigón sur de Playa Santa María del Mar y descansa sobre laja rocosa que sirve de protección natural al oleaje incidente; y (2) la sección central u Hotel Victoria (HV), que es una playa disipativa expuesta al oleaje frente al hotel del mismo nombre.

Los perfiles se realizaron de manera perpendicular a la costa utilizando una estación total Leica TC407 y un prisma con base graduada de $5 \mathrm{~m}$. Esta estación permite medir ángulos verticales y horizontales, y está provista de una cruz filial con un par de hilos estadimétricos con los cuales se calcula la diferencia en la altura del terreno (distancias y desnivel). Se empleó la nivelación diferencial (King 1972), que es la metodología clásica usada en los estudios de morfodinámica. Los perfiles topográficos fueron espaciados homogéneamente a lo largo de toda el área de estudio, cada $30 \mathrm{~m}$. La longitud de los perfiles dependía del ancho de la playa, de la pendiente y del nivel del mar en el momento de realizar la campaña, de manera que en la sección HV los perfiles tuvieron una longitud aproximada de $180 \mathrm{~m}$ y un error en $z$ de $\pm 0.02 \mathrm{~m}$, mientras que en la sección FV su longitud aproximada fue de $70 \mathrm{~m}$ y un error en $z$ de $\pm 0.02 \mathrm{~m}$. Las campañas se realizaron con una periodicidad de 15 días de febrero a octubre de 2004.

El seguimiento topográfico permite reconstruir las características morfológicas de las playas cuyo volumen se estima por medio del largo y ancho medido en los perfiles. Estos resultados se compararon mediante el programa Surfer (versión 8) usando el método de interpolación de Kriging, y obteniendo así el sedimento depositado y/o erosionado en las distintas campañas de muestreo.

La granulometría se realizó con muestras de sedimento recolectadas de la zona intermareal, por ser ésta la parte donde se registran las mayores variaciones granulométricas (Benavente 2000). La toma de muestras fue simultánea a la 
$30 \mathrm{~m}$, in order to cover all the study area. Profile length depended on beach width, slope, and sea level at the time of the survey. The approximate length of the profiles in section HV was $180 \mathrm{~m}$ (with a $z$ error of $\pm 0.02 \mathrm{~m}$ ), while that of the profiles in section FV was $70 \mathrm{~m}$ ( $z$ error of $\pm 0.02 \mathrm{~m}$ ). Profiles were taken every 15 days from February to October 2004.

Continuous topographic measurements allow reconstruction of the morphological characteristics of a beach, the length and width determined by the profiles providing volume data. The results were compared using Surfer Software (version 8) and the Kriging interpolation method, and the amount of sediment deposited and/or eroded during the different surveys was determined.

For grain size analysis, sediment samples were collected from the intertidal zone since most granulometric variations occur in this part (Benavente 2000). Surface sediments (approximately the top $30 \mathrm{~cm}$ ) were collected with a small shovel at the same time as profiles were taken and at the same distances (Benavente 1997). Around $200 \mathrm{~g}$ were taken in order to also analyze the carbonate $\left(\mathrm{CaCO}_{3}\right)$ content in each sample.

Sediment samples collected from section HV were used for textural analysis, since greater granulometric variations occur along this part of the beach. Laboratory work was carried out at the Department of Crystallography, Mineralogy, Stratigraphy, Geodynamics, Petrology, and Geochemistry of Cádiz University. Sediments were sieved and parameters were obtained using the method of moments described by Folk (1974).

The $\mathrm{CaCO}_{3}$ content was determined using a Bernard calcimeter (Wiesmann and Nehring 1951). From the results of the replicas, the mean percentage was obtained, which was the representative percentage for each sample. A graph was then plotted to determine the area where $\mathrm{CaCO}_{3}$ predominated.

Littoral transport was estimated by staining sediment with fluorescent paint containing toluene to prevent the compaction of sediment grains. About $10 \mathrm{~kg}$ of sediment from the beach face were painted to conserve both the granulometric and hydrodynamic characteristics (Ingle 1966, Teleki 1966, Yasso 1966). The painted sand was replaced on the beach face of section $\mathrm{HV}$, and at the end of the tide cycle samples were collected from all along the beach for analysis using the spatial integral method (Horikawa 1988). To determine the distribution of grains in the study area, painted grains were counted with a fluorescent lamp, and Surfer Software (version 8) was used to plot a two-dimensional graph that showed the distribution of the tracers along the beach.

To analyze sediment transport, the fluorescent tracer method was applied to calculate the distance covered (y) considering the distance travelled from the center of mass of the tracers, using the equation of the integration method proposed by Komar (1969):

$$
y=\sum P_{i} d_{i} / \sum P_{i}
$$

where $P_{i}$ is the quantity of stained grains observed in cell $i$, and $d_{i}$ is the distance at which that cell is from the original point. realización de los perfiles y en forma equidistante, tomando sedimento superficial con una pala pequeña hasta aproximadamente $30 \mathrm{~cm}$ de profundidad (Benavente 1997). También se tomaron alrededor de $200 \mathrm{~g}$ para analizar el contenido de carbonatos $\left(\mathrm{CaCO}_{3}\right)$ en cada muestra.

El análisis textural se realizó con muestras de sedimento obtenidas en la sección HV, por ser la parte de la playa donde se registran las mayores variaciones granulométricas. Este se realizó en el laboratorio del Departamento de Cristalografía y Mineralogía, Estratigrafía, Geodinámica, Petrología y Geoquímica de la Universidad de Cádiz, por medio de tamizado, y los parámetros se obtuvieron con el método de los momentos descrito por Folk (1974).

Para determinar el contenido de $\mathrm{CaCO}_{3}$ se hizo un análisis composicional por medio del calcímetro de Bernard (Wiesmann y Nehring 1951). Con el resultado de las réplicas se sacó la media porcentual, misma que representó el porcentaje para cada muestra. Posteriormente se realizó una gráfica en la cual se muestra la zona en la que predomina el $\mathrm{CaCO}_{3}$.

El transporte litoral se estimó tiñendo sedimento con pintura fluorescente con disolvente que contenía tolueno para evitar la compactación de los granos de sedimento. Se pintaron 10 $\mathrm{kg}$ de sedimento de la cara de la playa con el fin de conservar sus características tanto granulométricas como hidrodinámicas (Ingle 1966, Teleki 1966, Yasso 1966). La arena pintada se volvió a sembrar en la cara de la playa de la sección HV, y al final del ciclo mareal se tomaron muestras a lo largo de toda la playa para hacer un análisis con el método integral espacial (spatial integral method, SIM) (Horikawa 1988). Para determinar la distribución de granos a lo largo del área de muestreo, se contaron granos pintados con ayuda de una lámpara fluorescente, y por medio del programa Surfer (ver. 8) se hizo una gráfica bidimensional donde se aprecia la distribución de trazadores a lo largo de la playa.

Para el análisis de transporte sedimentario, por medio del método de trazadores fluorescentes se calculó la distancia recorrida $(y)$ considerando la distancia a partir del centro de masa de los trazadores. Para esto se utilizó la fórmula del método de integración propuesta por Komar (1969):

$$
y=\sum P_{i} d_{i} / \sum P_{i}
$$

donde $P_{i}$ es la cantidad de granos teñidos que aparecen en la celda $i$, y $d_{i}$ es la distancia a la que se encuentra dicha celda del punto de siembra.

La velocidad de transporte sedimentario se calculó dividiendo la distancia recorrida entre el tiempo utilizado para ello, $V_{t}=y / t$, en este caso la duración del ciclo mareal (12 h $\left.16 \mathrm{~min}\right)$.

\section{Resultados}

\section{Perfiles topográficos}

\section{Sección norte (Final Victoria)}

En marzo de 2004, en la zona de rompiente la pendiente decreció homogéneamente en toda el área con rompiente tipo 
Sediment transport velocity was calculated dividing the distance covered by the time selected for this analysis, in this case the length of the tide cycle $(12 \mathrm{~h} 16 \mathrm{~min}): V_{t}=y / t$.

\section{Results}

\section{Topographic profiles}

\section{Northern section (Final Victoria)}

In March 2004, the slope in the breaker zone (collapsing breaking waves) decreased homogeneously throughout the area. Profile height decreased in the northern part of this section; in the southern part, the height of the beach face also decreased presenting two berm ridges, characteristic of its upper part, and a berm channel (fig. 2). In the central part, the beach face was more extensive and had an abrupt slope towards the breaker zone.

By April, accumulation had occurred in the northern part of FV. The central part showed slight depressions along the beach face and the two berm ridges were no longer noticeable parallel to the coast (fig. 3). This survey revealed accumulation on the beach face, a decreased bar in the first $50 \mathrm{~m}$ of the northern part, and erosion of the beach face in the southern part.

In May, a channel appeared in the first $50 \mathrm{~m}$ with northsouth direction, parallel to the coastline, which slowly dissipated until disappearing completely. Sinking was observed in the southern part as a result of the urban drainage system (fig. 4). Stepping was also observed in the northern part of the berm, as well as depressions along the rest of the beach face and modification of the sinking caused by the urban drainage.

In June, the northern part continued to present stepping and the central part of the berm presented erosion. Two small accumulations were observed in the lower part of the beach face in the northern and southern parts (fig. 5).

In October, the characteristics were very similar to those of the first survey (March). Once again, in the northern part the beach face had a flat section that extended along the beach, with small variations in the southern part (fig. 6).

\section{Central section (Hotel Victoria)}

Section HV is $180 \mathrm{~m}$ long. Its morphological characteristics were more homogenous during the study period, and there was less deposition and/or erosion. In March 2004, a soft slope and spilling breaker waves were observed. The most significant changes occurred in June and October, when bars were observed along the berm parallel to the coastline, with channels perpendicular to the coast.

\section{Sediment volumes}

Based on the topographic profiles, sediment volumes were calculated for the different surveys (table 1). For section FV, a volume of $112,311.76 \mathrm{~m}^{3}$ was determined for the first survey and of $75,755.26 \mathrm{~m}^{3}$ for the last, thus showing a decrease of colapsada (surfing); en el norte de esta sección la altura del perfil disminuyó; al sur de la misma sección la altura en la cara de la playa también disminuyó presentando dos cordones de bermas que caracterizan su parte superior y un canal en la berma (fig. 2). En el centro, la cara de la playa era más extensa y tenía una pendiente abrupta hacia la zona de rompiente.

Para abril hubo una acumulación en la parte norte de FV. La parte central presentaba ligeras depresiones en la cara de la playa y, notablemente, ya no se estaban definidos los cordones de la berma que estaban al sur, paralelos a la costa (fig. 3). Esta campaña presentó acumulación en la cara de playa, y con la disminución de la barra en los primeros $50 \mathrm{~m}$ de la parte norte, también se presentó erosión en la cara de playa hacia el sur.

En mayo se presentó un canal en los primeros $50 \mathrm{~m}$ con dirección norte-sur, paralelo a la línea de costa, que se fue disipando hasta desaparecer por completo. Resalta el hundimiento de la parte sur debida al sistema de drenaje urbano (fig. 4). También se registró escalonamiento en la parte norte de la berma, así como depresiones en el resto de la cara de la playa y se modificó el hundimiento por el drenaje urbano.

En junio continúa el escalonamiento en la parte norte y la erosión de la berma en la parte central. En la parte baja de la cara de la playa hay dos pequeñas acumulaciones en las partes norte y sur (fig. 5).

En octubre las características son muy parecidas a la primera campaña (marzo): en la parte norte nuevamente se notaba una parte plana en la cara de la playa que se extendía a lo largo de la misma, con pequeñas variaciones en el sur (fig. 6).

\section{Sección central (Hotel Victoria)}

La sección HV tiene una longitud de $180 \mathrm{~m}$. Sus características morfológicas fueron más homogéneas durante el periodo de muestreo, sin tanta depositación y/o erosión. En marzo presentó una pendiente suave con rompiente tipo derrame (spilling). Los cambios más significativos fueron medidos en junio y octubre, cuando se presentaron barras en la berma paralelas a la línea de costa, con canales perpendiculares a la costa.

\section{Volúmenes de sedimento}

A partir de los perfiles topográficos se obtuvieron los volúmenes de sedimento para las distintas campañas de muestreo (tabla 1). La sección FV presentó en la primera campaña un volumen de $112,311.76 \mathrm{~m}^{3}$, y en la última uno de $75,755.26 \mathrm{~m}^{3}$, mostrando una disminución de 36,556.5 $\mathrm{m}^{3}$. Para la sección $\mathrm{HV}$, en cambio, en la primera campaña se obtuvo un volumen de $20,906.35 \mathrm{~m}^{3}$, y en la última uno de $122,187.81 \mathrm{~m}^{3}$, indicando un aumento de $101,281.46 \mathrm{~m}^{3}$.

\section{Análisis textural}

Se analizaron un total de 24 muestras de sedimento recolectadas en la zona intermareal de la sección HV, la cual se dividió 


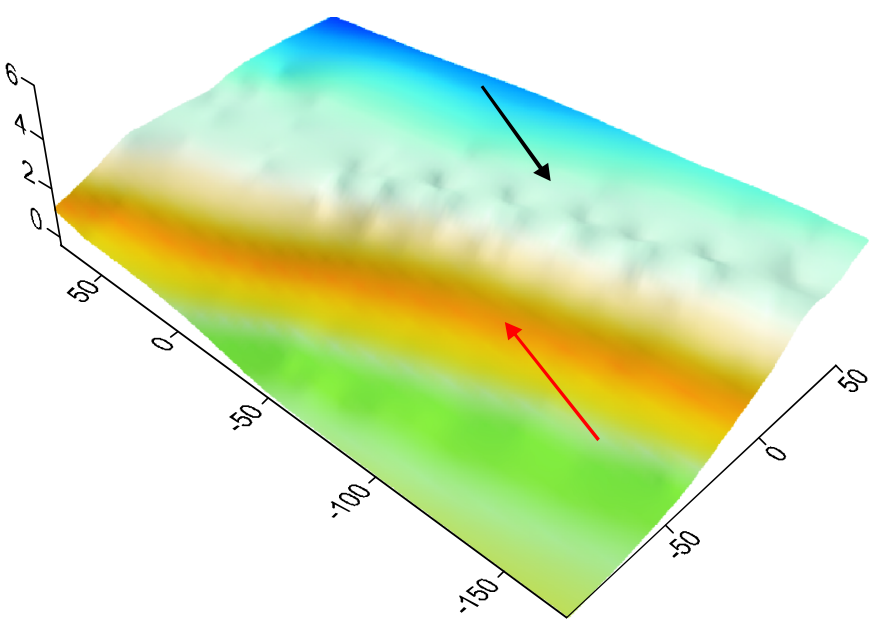

Figure 2. Three-dimensional section for March 2004. The red arrow indicates the much steeper part and the black arrow the berm channel in section Final Victoria.

Figura 2. Sección tridimensional durante marzo de 2004. La flecha roja indica la parte con mucho mayor pendiente y la flecha negra el canal en la berma en la sección Final Victoria.

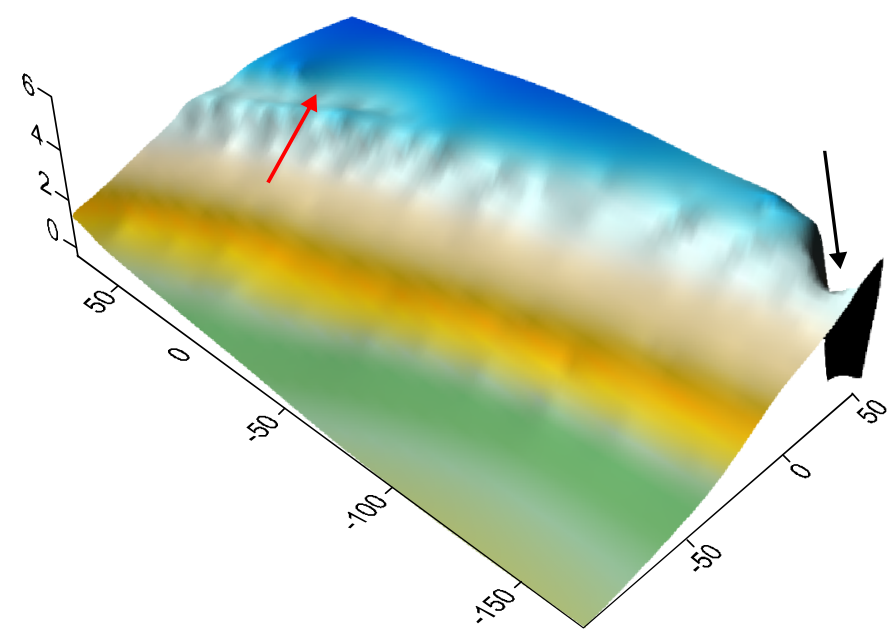

Figure 4. Three-dimensional section for May 2004. The red arrow indicates the presence of the channel in the first $50 \mathrm{~m}$ of section Final Victoria and the black arrow the sinking caused by the urban drainage system.

Figura 4. Sección tridimensional durante mayo de 2004. La flecha roja indica la presencia de un canal ubicado en los primeros $50 \mathrm{~m}$ de la sección Final Victoria y la flecha negra el hundimiento provocado por el sistema de drenaje urbano.

$36,556.5 \mathrm{~m}^{3}$. For section HV, a volume of $20,906.35 \mathrm{~m}^{3}$ was recorded for the first survey and of $122,187.81 \mathrm{~m}^{3}$ for the last, indicating an increase of $101,281.46 \mathrm{~m}^{3}$.

\section{Textural analysis}

A total of 24 sediment samples were collected from the intertidal zone of section $\mathrm{HV}$, which was divided into three transects (V1, V2, V3) parallel to the coastline (table 2). Mean grain size was $2-3$ phi during the study period, corresponding

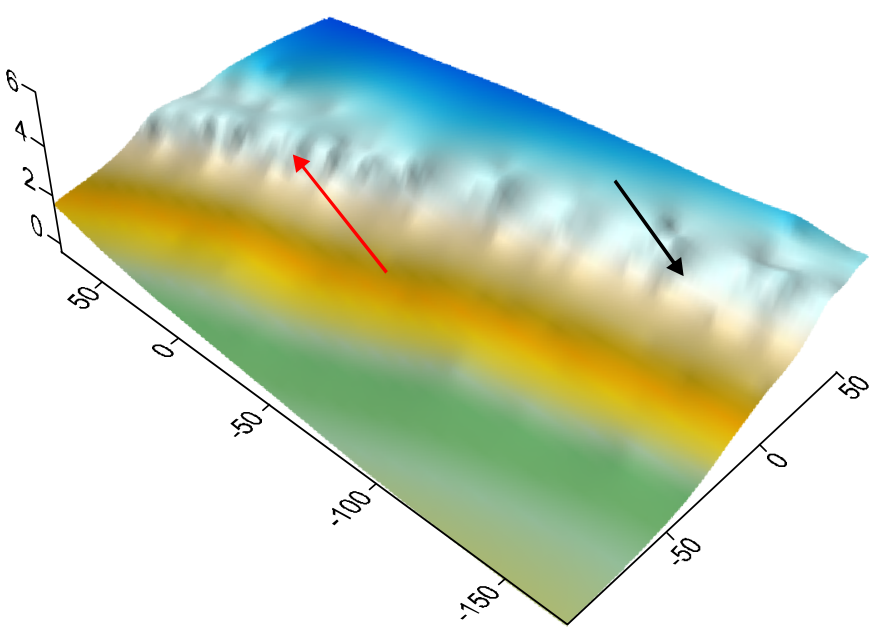

Figure 3. Three-dimensional section for April 2004. The red arrow indicates accumulation in section Final Victoria and the black arrow the erosion on the berm face.

Figura 3. Sección tridimensional durante abril de 2004. La flecha roja indica acumulación en la sección Final Victoria y la flecha negra erosión en la berma.

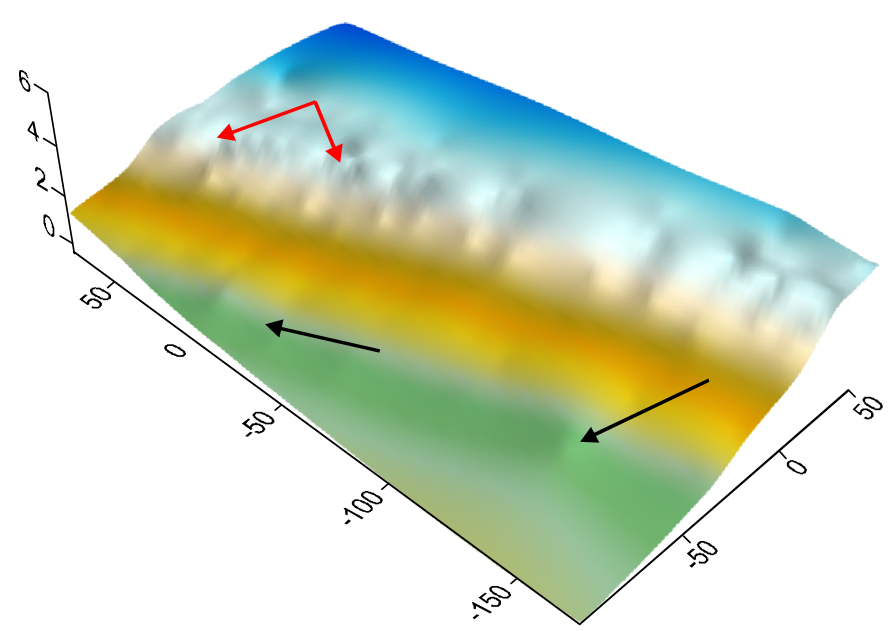

Figure 5. Three-dimensional section for June 2004. The red arrows indicate stepping along the berm and the black arrows accumulation in the lower part of the beach face in section Final Victoria?.

Figura 5. Sección tridimensional durante junio de 2004 Las flechas rojas muestran el escalonamiento en la zona de berma y las flechas negras acumulación de la parte inferior de la cara de la playa en la sección Final Victoria.

en tres transectos (V1, V2, V3) paralelos a la línea de costa (tabla 2). Su tamaño medio de grano durante el periodo de muestreo fue de 2 a 3 phi; esto es arena fina según la clasificación de Wentworth (1922). La clasificación o desviación estándar $(\sigma)$, en promedio 0.67 , caracteriza a la playa como moderadamente bien clasificada (Folk 1966). La asimetría (sk) mostró un valor de -0.33 , con una tendencia fuertemente asimétrica hacia los gruesos. La kurtosis (k), de 4.99, corresponde a una distribución extremadamente leptocúrtica (Folk 1966). Por ende, la distribución está más sesgada a los finos, dado que 
to fine sand according to the classification proposed by Wentworth (1922). The sorting or standard deviation $(\sigma)$, with a mean of 0.67 , indicated that the beach fell into the moderately well classified category (Folk 1966). A value of -0.33 was obtained for asymmetry (sk), indicating a strong asymmetric tendency towards thick grain sizes. Kurtosis (k) was 4.99, corresponding to an extremely leptokurtic distribution (Folk 1966). This means that grain size distribution was biased towards fine sizes, with the highest percentage of sediments retained in the 2 and 3 phi sieves (fig. 7).

\section{Fluorescent tracers}

To determine the littoral transport, the distance travelled by the tracers was calculated (fig. 8). Dilution was not very high, and the tracers moved less than $200 \mathrm{~m}$ to the south of the initial injection point, which had the greatest concentration. In general, a southward, offshore transport was observed, with a displacement of $130 \mathrm{~m}$ at a speed of $0.29 \mathrm{~m} \mathrm{~s}^{-1}$.

\section{Carbonate content}

Carbonate content ranged from $3.5 \%$ to $9.5 \%$ in the 24 samples analyzed, and was more dominant in the part closest to the breaker zone, with a concentration of $9 \%$, whereas it was only $3 \%$ at the berm. In section $\mathrm{HV}, \mathrm{CaCO}_{3}$ content ranged from $5 \%$ to $6 \%$ (fig. 9).

\section{Discussion}

The topographic surveys done in section FV show a clear reduction in the beach profile and a steeper slope than HV. This can be attributed to the rocky platform in this section, which is responsible for the erosion during the sampling period, increasing the beach slope and producing a morphological deficit after the 2003 winter period. This is because of the sudden increase in friction between the wave and bottom, causing the wave to increase in height and break with greater force, thus removing the sediment.

In June 2004, section HV showed an increase in beach width and a soft slope. This is characteristic of a dissipative beach with spilling breakers and little wave incidence. Komar (1998) associated this with the effect of constructive waves that characterize the summer period. An increase in the extent of the beach face was recorded in October as a result of the volume of sand that was artificially introduced $\left(485,000 \mathrm{~m}^{3}\right)$ during the summer months (August-September 2004), resulting in an increase in volume of $435,000 \mathrm{~m}^{3}$ for section FV. Evidently it was not possible to accurately determine the natural change; however, since sand is deposited at certain intervals, this information will serve as reference for future studies. When La Victoria Beach was regenerated in the spring of 1991, the part of the beach with a rocky platform (section FV) was found to have a higher rate of sediment loss than section $\mathrm{HV}$. In the 1991 regeneration project, $50,000 \mathrm{~m}^{3}$ were added at a el mayor porcentaje de sedimento fue retenido en los tamices de 2 y 3 phi (fig. 7).

\section{Trazadores fluorescentes}

Con el objeto de obtener el transporte litoral, se determinó la distancia que habían recorrido los trazadores (fig. 8). No se observó mucha dilución, el movimiento no fue mayor a $200 \mathrm{~m}$ al sur del punto de siembra, donde se registró la mayor concentración. En general, el transporte se produjo hacia el sur con tendencia mar adentro (perpendicular a la costa), con un desplazamiento de $130 \mathrm{~m}$ a una velocidad de $0.29 \mathrm{~m} \mathrm{~s}^{-1}$.

\section{Contenido de carbonatos}

Se analizó el contenido de carbonatos de un total de 24 muestras, en las cuales se obtuvo una concentración entre $3.5 \%$ y $9.5 \%$ de $\mathrm{CaCO}_{3}$. Éste se presentó en mayor proporción en la parte más cercana a la rompiente, con una concentración de $9 \%$, mientras que en la berma sólo se encontró un 3\%, y en la sección $\mathrm{HV}$ se encontraron concentraciones alrededor del 5\% al $6 \%$ de $\mathrm{CaCO}_{3}$ (fig. 9).

\section{Discusión}

Los levantamientos topográficos en la sección FV muestran una clara disminución del perfil de playa con pendiente más abrupta que HV. Posiblemente esto se deba a que la playa está sobre laja rocosa que es la responsable de la erosión durante el periodo de estudio, aumentando la pendiente de la playa y provocando un déficit en su morfología después de los temporales del invierno de 2003. Esto es porque el roce de la ola con el fondo se puede incrementar repentinamente, haciendo que ésta aumente su altura y colapse con mayor energía sobre la cara de la playa removiendo el sedimento.

Durante junio la sección HV presentó un aumento en el ancho de la playa y una pendiente suave, características de una playa disipativa con rompiente en derrame y con poca incidencia de oleaje. Komar (1998) relaciona este fenómeno con el efecto de oleaje constructivo que caracteriza a la temporada de verano. En octubre se registró un aumento en la extensión de la cara de la playa debido a la alimentación artificial de arena que se hizo durante los meses de verano (agosto a septiembre de 2004), en donde se vertieron 485,000 $\mathrm{m}^{3}$ de arena, teniendo un relleno para la sección FV de 435,000 $\mathrm{m}^{3}$. Es evidente que esto impidió determinar el cambio natural de manera precisa; sin embargo, debido a que el relleno de sedimento se realiza periódicamente, queda como un registro para su seguimiento y para futuros estudios. Como sucedió en la primavera de 1991, cuando se regeneró Playa de la Victoria y se comprobó que en la parte sobre laja rocosa (sección FV) la tasa de pérdida de sedimento es mayor que en la sección HV. En esta última el relleno fue sólo de $50,000 \mathrm{~m}^{3}$, vertidos a razón de $170 \mathrm{~m}^{3}$ por metro lineal, lo que representó un tercio de lo vertido entonces en la sección FV $\left(510 \mathrm{~m}^{3}\right.$ por metro lineal). 


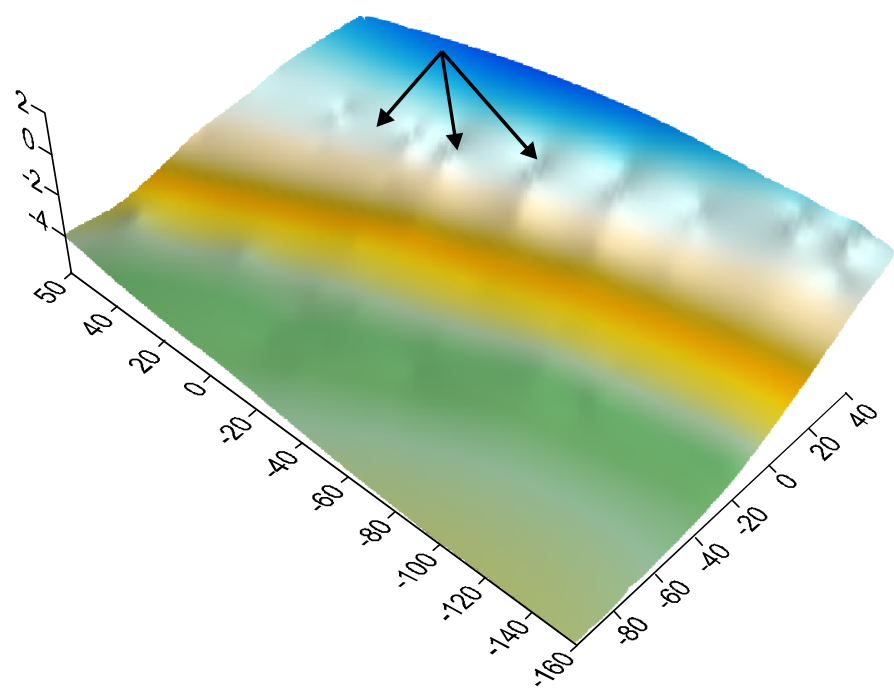

Figure 6. Three-dimensional section for October 2004. To the north of section Final Victoria it is flat (left of the arrows) and berm development (arrows) is observed; to the south there is little berm variation.

Figura 6. Sección tridimensional durante octubre de 2004. La parte norte de la sección Final Victoria es plana (izquierda de las flechas) y se observa el desarrollo de berma (flechas); y hacia el sur hay poca variación en la berma.

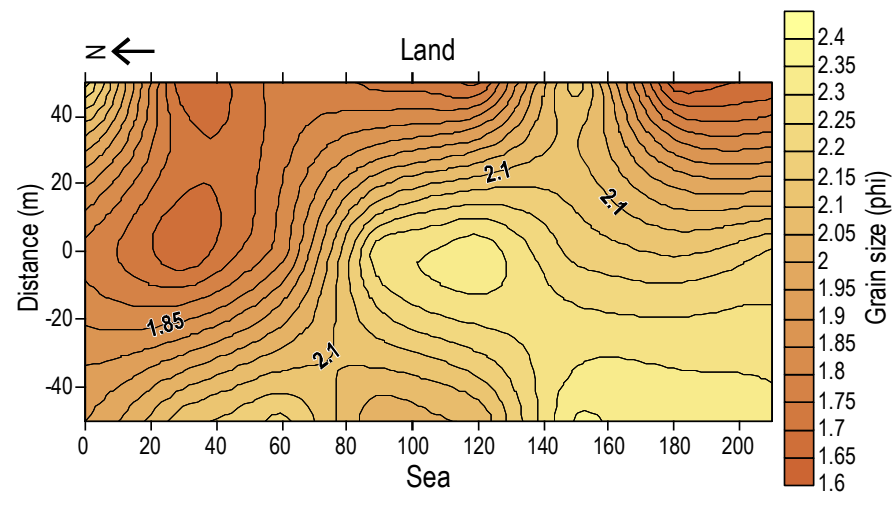

Figure 7. Spatial distribution of the grain size for La Victoria Beach.

Figura 7. Distribución espacial del tamaño de grano en Playa de la Victoria.

rate of $170 \mathrm{~m}^{3}$ per linear meter, representing a third of that introduced into section $\mathrm{FV}\left(510 \mathrm{~m}^{3}\right.$ per linear meter $)$. This corroborates the morphological dynamic differences of the beaches in both sections, and confirms the higher rate of erosion at FV.

From March to October 2004, the difference in volume found for section $\mathrm{HV}$ was $101,281.46 \mathrm{~m}^{3}$ in an area of $27,988.54 \mathrm{~m}^{2}$, indicating a deposition process and concurring with the profile analysis that revealed an increase in beach width. This corroborates the classical summer deposition pattern reported by Komar (1998), due to the constructive waves that remove the sediments from the bars formed around the breaker zone. For section FV, the difference in volume found was $-36,556.5 \mathrm{~m}^{3}$ in an area of $33,551.07 \mathrm{~m}^{2}$, clearly indicating an erosion process. As already mentioned, this can

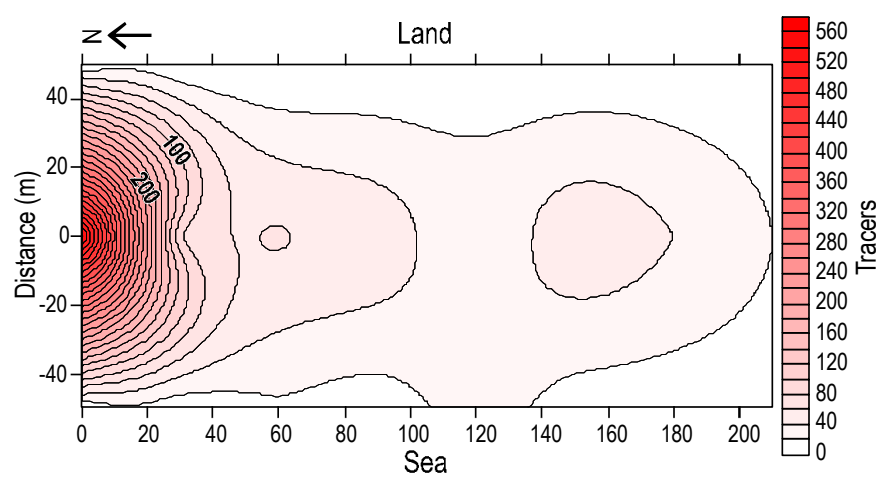

Figure 8. Distribution of the fluorescent tracers along La Victoria Beach (0, $0=$ injection point).

Figura 8. Distribución de trazadores a lo largo de Playa de la Victoria. El punto $(0,0)$ indica el punto de inyección.

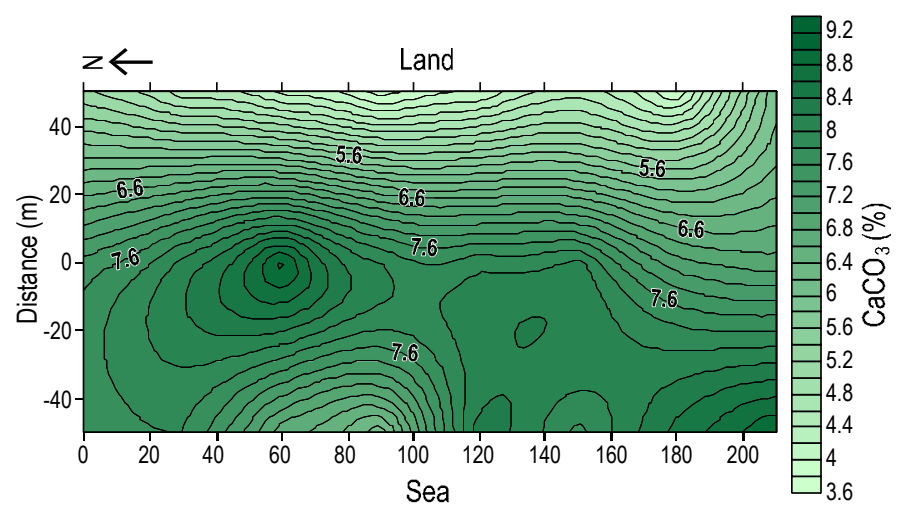

Figure 9. Spatial distribution of the concentration of carbonates at La Victoria Beach.

Figura 9. Distribución espacial de la concentración de carbonatos en Playa de la Victoria.

Esto corrobora las diferencias dinámicas morfologícas entre las playas en ambas secciones, y confirma la mayor tasa de erosión de FV.

De marzo a octubre de 2004, la diferencia de volumen encontrada para la sección HV fue de $101,281.46 \mathrm{~m}^{3}$ en un área de $27,988.54 \mathrm{~m}^{2}$, lo cual indica un proceso de depositación y concuerda con el análisis de los perfiles que pone de manifiesto el aumento del ancho de la playa. Esto corrobora el patrón clásico de depositación en verano reportado por Komar (1998), debido al oleaje constructivo que remueve sedimento de las barras formadas alrededor de la zona de rompiente. Para la sección FV la diferencia de volumen encontrada fue de -36,556.5 $\mathrm{m}^{3}$ en un área de $33,551.07 \mathrm{~m}^{2}$, la cual indica claramente un proceso de erosión. Como ya se mencionó, éste se debe a la laja rocosa en la que está apoyada la playa, así como al cambio de energía debido a los vientos de Levante que ocurren durante esta temporada (Benavente 2000), y que producen oleaje de mayor altura y energía haciendo que el sedimento sea removido hacia el mar.

Los parámetros estadísticos encontrados para la sección HV muestran la presencia de dos grupos de sedimento, el primero de arenas finas que se encuentran cerca de la rompiente y 
Table 1. Total sediment volume in the surveys conducted. The difference was calculated between the 9 March and 15 October 2004 surveys. Tabla 1. Volumen total del sedimento en las campañas realizadas. La diferencia se realizó entre la campaña del 9 de Marzo y la del 15 de Octubre de 2004.

\begin{tabular}{ccc}
\hline $\begin{array}{c}\text { Survey } \\
(\mathrm{d} / \mathrm{m} / \mathrm{yr})\end{array}$ & $\begin{array}{c}\text { Hotel Victoria } \\
\text { section }\end{array}$ & $\begin{array}{c}\text { Final Victoria } \\
\text { section }\end{array}$ \\
\hline $09 / 03 / 2004$ & $20,906.35 \mathrm{~m}^{3}$ & $112,311.76 \mathrm{~m}^{3}$ \\
$03 / 04 / 2004$ & $75,520.09 \mathrm{~m}^{3}$ & $316,350.15 \mathrm{~m}^{3}$ \\
$20 / 04 / 2004$ & $83,311.35 \mathrm{~m}^{3}$ & $111,900.44 \mathrm{~m}^{3}$ \\
$04 / 05 / 2004$ & $73,349.40 \mathrm{~m}^{3}$ & $100,908.90 \mathrm{~m}^{3}$ \\
$18 / 05 / 2004$ & $75,566.62 \mathrm{~m}^{3}$ & $102,695.37 \mathrm{~m}^{3}$ \\
$03 / 06 / 2004$ & $83,880.91 \mathrm{~m}^{3}$ & $316,350.15 \mathrm{~m}^{3}$ \\
$15 / 10 / 2004$ & $122,187.81 \mathrm{~m}^{3}$ & $75,755.26 \mathrm{~m}^{3}$ \\
\hline Difference & $101,281.46 \mathrm{~m}^{3}$ & $-36,556.50 \mathrm{~m}^{3}$ \\
Surface area & $27,988.54 \mathrm{~m}^{2}$ & $33,551.07 \mathrm{~m}^{2}$ \\
\hline
\end{tabular}

be attributed to the rocky platform and to the change in energy due to the trade winds that occur during this period (Benavente 2000), increasing the height and energy of the waves with the consequent offshore removal of sediment.

The statistical parameters obtained for section HV show the occurrence of two sediment groups, one consisting of fine sands close to the breaker zone and the other of very fine pebbles at the berm. Sunamura and Horikawa (1978) reported that sediment transport occurs under similar textural conditions, and in the area surveyed, the preferential direction was from north to south. This is also indicative of beaches with well classified sediments, since most of the sediment is of the same type, a characteristic that results in a reduction in beach permeability and directly affects the intertidal slope (Benavente 2000).

The grain size analysis indicated a predominance of fine grains towards the south (fig. 7), coinciding with the fluorescent tracers (fig. 8). This concurs with the NW-SE direction of the littoral transport reported by Melierés (1974) and Ojeda (1989), who analyzed the sedimentary dynamics of the Gulf of Cádiz and the recent coastal dynamics of the west coast of Andalusia, respectively. Moreover, the sediment presented the same displacement as that found by Muñoz-Pérez et al. (1999) using fluorescent tracers in SW Spain, similar to the littoral transport and perpendicular to the coast due to wave movement, with the known rewashing as a result of the waves encroaching and receding from the beach face (Kraus et al. 1982).

The distribution of $\mathrm{CaCO}_{3}$ at $\mathrm{La}$ Victoria Beach showed a higher concentration in the breaker zone (fig. 9), related to the distribution of fine grains. In a study on the littoral morphodynamics of the external Cádiz bay, Benavente (2000) found that the concentration of $\mathrm{CaCO}_{3}$ was higher when the grain size was larger. This occurs because the concentration of $\mathrm{CaCO}_{3}$ is much lower than that of any other sediment component and is thus easily removed by wave action. The behaviour of $\mathrm{CaCO}_{3}$ el segundo de guijarros muy finos localizados en la berma. Esto se relaciona con el criterio de Sunamura y Horikawa (1978), quienes indican que en condiciones texturales similares existe transporte de sedimento, y en el área estudiada la dirección preferentemente resultó ser de norte a sur. Esto también es un indicativo de playas con sedimentos muy bien clasificados, ya que el mayor porcentaje de sedimento es prácticamente del mismo tipo, lo que provoca la disminución de la permeabilidad de la playa incidiendo directamente en la pendiente intermareal (Benavente 2000).

La granulometría presentó una predominancia de granos finos hacia el sur (fig. 7), lo que coincide con los resultados obtenidos mediante el uso de trazadores fluorescentes (fig. 8). Esto concuerda con la dirección del transporte litoral de NW a SE reportado para la zona por Meliéres (1974) y Ojeda (1989), quienes analizaron la dinámica sedimentaria en el Golfo de Cádiz y la dinámica litoral reciente en la costa occidental de Andalucía, respectivamente. Asimismo, el sedimento presentó el mismo desplazamiento encontrado por Muñoz-Perez et al. (1999) por medio de trazadores fluorescentes al SW de España, similar al transporte litoral y perpendicular a la costa por el efecto del movimiento de la ola con el conocido relavado que se debe a la incidencia de la ola sobre la cara de la playa y por el retroceso de la misma (Kraus et al. 1982).

La distribución de $\mathrm{CaCO}_{3}$ en Playa de la Victoria registró una mayor concentración en la zona de rompiente (fig. 9), relacionada con la distribución de los granos finos. Benavente (2000) realizó un estudio sobre la morfodinámica litoral en la bahía externa de Cádiz, donde menciona que a mayor tamaño de grano, mayor es la concentración de $\mathrm{CaCO}_{3}$. Esto se debe a que la concentración del $\mathrm{CaCO}_{3}$ es mucho menor que la de cualquier otro componente de los sedimentos, por lo tanto es fácilmente removido por la acción del oleaje. En la sección HV el $\mathrm{CaCO}_{3}$ resultó con máximas concentraciones en zonas donde predominaban los tamaños finos lo que se contrapone a lo 
Table 2. Textural parameters in phi units for section Hotel Victoria of La Victoria Beach. Tabla 2. Parámetros texturales en unidades phi $(\varphi)$, de la sección Hotel Victoria de Playa de la Victoria.

\begin{tabular}{|c|c|c|c|c|c|}
\hline Profile & Point & Mean & Deviation & Asymmetry & Kurtosis \\
\hline V-1 & A & 2.9 & 0.5 & -0.1 & 3.4 \\
\hline $\mathrm{V}-1$ & $\mathrm{~B}$ & 3.4 & 0.5 & 0.6 & 4.0 \\
\hline $\mathrm{V}-1$ & $\mathrm{C}$ & 2.6 & 0.5 & 0.7 & 2.7 \\
\hline $\mathrm{V}-1$ & $\mathrm{D}$ & 2.5 & 0.5 & 0.4 & 3.4 \\
\hline V-1 & $\mathrm{E}$ & 2.5 & 0.5 & 0.6 & 4.0 \\
\hline V-1 & $\mathrm{F}$ & 2.8 & 0.5 & -0.3 & 3.8 \\
\hline $\mathrm{V}-1$ & G & 2.4 & 0.4 & 0.5 & 4.0 \\
\hline V-1 & $\mathrm{H}$ & 2.4 & 0.5 & -0.1 & 6.0 \\
\hline $\mathrm{V}-2$ & $\mathrm{~A}$ & 2.5 & 0.7 & -0.4 & 4.7 \\
\hline $\mathrm{V}-2$ & B & 2.4 & 0.6 & 0.0 & 5.0 \\
\hline $\mathrm{V}-2$ & $\mathrm{C}$ & 2.5 & 0.7 & -0.4 & 4.8 \\
\hline $\mathrm{V}-2$ & $\mathrm{D}$ & 2.9 & 0.6 & -0.4 & 5.2 \\
\hline $\mathrm{V}-2$ & $\mathrm{E}$ & 3.0 & 0.7 & -0.8 & 7.1 \\
\hline $\mathrm{V}-2$ & $\mathrm{~F}$ & 2.8 & 0.8 & -1.2 & 7.0 \\
\hline $\mathrm{V}-2$ & $\mathrm{G}$ & 2.7 & 0.7 & -0.8 & 6.1 \\
\hline $\mathrm{V}-2$ & $\mathrm{H}$ & 2.8 & 0.6 & -0.8 & 4.7 \\
\hline $\mathrm{V}-3$ & A & 2.6 & 0.8 & -0.6 & 4.8 \\
\hline V-3 & B & 2.8 & 0.7 & -0.6 & 5.0 \\
\hline $\mathrm{V}-3$ & $\mathrm{C}$ & 2.8 & 0.7 & -0.6 & 4.7 \\
\hline V-3 & $\mathrm{D}$ & 2.7 & 0.6 & -0.6 & 6.2 \\
\hline V-3 & $\mathrm{E}$ & 2.7 & 0.7 & -0.8 & 5.4 \\
\hline V-3 & $\mathrm{F}$ & 3.0 & 0.7 & -0.4 & 5.0 \\
\hline$V-3$ & G & 2.9 & 0.8 & -0.7 & 5.3 \\
\hline \multirow[t]{2}{*}{ V-3 } & $\mathrm{H}$ & 2.9 & 0.8 & -0.9 & 6.2 \\
\hline & Average & 2.7 & 0.6 & -0.3 & 4.9 \\
\hline
\end{tabular}

in the Hotel Victoria section showed maximum $\mathrm{CaCO}_{3}$ content in areas dominated by fine grains, differing from that reported by Benavente (2000). This indicates the instability of the beach depending on the sampling date.

\section{Acknowledgements}

The second author acknowledges receipt of a scholarship from the Autonomous University of Baja California for the stay at Cádiz. We thank the University of Cádiz for the use of their facilities and providing the material necessary to process the samples, as well as A Ghetti for assistance with the topographic profiles.

English translation by Christine Harris.

\section{References}

Anfuso G. 2001. Morfología y dinámica sedimentaria del litoral gaditano entre Chipiona y Rota. Ph.D. thesis, Univ. Cádiz, 375 pp. descrito por Benavente (2000) y podría indicar inestabilidad de la playa el día en que se realizó el muestreo.

\section{Agradecimientos}

El segundo autor agradece a la Universidad Autónoma de Baja California por la beca otorgada para la estancia en Cádiz. Se agradece a la Universidad de Cádiz el uso de sus instalaciones y materiales necesarios en el procesamiento de las muestras, así como a A Ghetti por su ayuda en la medición de los perfiles topográficos.

Benavente J. 1997. Introducción al estudio de la dinámica sedimentaria de las playas del norte de la Bahía de Cádiz: Vistahermosa, Santa Catalina y La Puntilla. B.Sc. thesis, Univ. Cádiz, 192 pp.

Benavente J. 2000. Morfodinámica litoral de la bahía externa de Cádiz. Ph.D. thesis, Univ. Cádiz, 534 pp.

Carter RWG. 1988. Coastal Environments. Academic Press, 617 pp. 
CERC, Coastal Engineering Research Center. 1984. Shore Protection Manual. US Army Corps of Engineers, Coastal Engineering Research Center, Printing Office, Washington.

CMAJA, Consejería de Medio Ambiente de la Junta de Andalucía. 1995. Medio Ambiente en Andalucía. Junta de Andalucía, Sevilla, $406 \mathrm{pp}$.

Folk RL. 1966. A review of grain size parameters. Sedimentology 6: 73-93.

Folk RL. 1974. Petrology of Sedimentary Rocks. Hemphill Publishing Co., Austin, Texas, 182 pp.

Horikawa K. 1988. Nearshore Dynamics and Coastal Processes. Univ. Tokyo Press, $522 \mathrm{pp}$.

Ingle JC. 1966. The Movement of Beach Sand. Elsevier, New York, $221 \mathrm{pp}$.

King CAM. 1972. Beaches and Coasts. 2nd ed. Arnold, London, $570 \mathrm{pp}$.

Komar PD. 1969. The longshore transport of sand on beaches. Ph.D thesis, Univ. California, San Diego, 143 pp.

Komar PD. 1998. Beach Processes and Sedimentation. Prentice-Hall, $544 \mathrm{pp}$

Kraus M, Masselink G, Hughes M. 1982. Field experiments on longshore sand transport in the surf zone. Proc. 18th Int. Conf. Coast. Eng. ASCE, pp. 626-644.

Melierés F. 1974. Reserches sur la dynamique sédimentarire du Golfe du Cadix (Espagne). Ph.D. thesis, Univ. Paris, $\mathrm{N}^{\circ} \mathrm{RC}$ CNRS AV 206, 8, 235 pp.

MOPU, Ministerio de Obras Públicas y Urbanismo. 1991. Actuaciones en la Costa. Secretaría General Técnica, Madrid, 307 pp.
Muñoz-Pérez JJ. 1996. Análisis de la morfología y variabilidad de playas apoyadas en lajas rocosas. Ph.D. thesis, Univ. Cádiz, $150 \mathrm{pp}$.

Muñoz-Pérez JJ, Gutiérrez-Mass JM, Parrado JM, Moreno L. 1999. Sediment transport velocity by tracer experiment at Regla Beach (Spain). J. Waterway Port Coast. Ocean Eng.: 332-335.

Muñoz JJ, López B, Gutiérrez JM, Moreno L, Cuena G. 2001. Cost of beach maintenance in the Gulf of Cadiz (SW Spain). Coast. Eng. 42: 143-153.

Ojeda J. 1989. Dinámica litoral reciente de la costa occidental de Andalucía. In: El Cuaternario en Andalucía Occidental. AEQUA, Monografías 1: 123-132.

Short A. 1979. Three dimensional beach stage model. J. Geol. 87: $553-571$.

Sunamura T, Horikawa L. 1978. Predominant direction of littoral transport along Kujyukuri Beach, Japan. Coast. Eng. Japan 14: 107-117.

Teleki PG. 1966. Fluorescent sand tracers. J. Sediment. Petrol. 36: 469-485.

Weisman M, Nehring K. 1951. Agrikulturchemisches Praktikum. Paul Parey, Berlin.

Wentworth CK. 1922. A scale of grade and class term for clastic sediment. J. Geol. 30: 377-392.

Yasso WE. 1966. Formulation and use of fluorescent tracer coatings in sediment transport studies. Sedimentology 6: 287-301.

Recibido en septiembre de 2008; aceptado en agosto de 2009. 